\title{
Societies take united stand on journal access
}

\section{Jim Giles, London}

More than 40 biomedical societies have banded together to counter calls for them to provide immediate and unrestricted access to the scientific literature they publish.

On 16 March, the societies launched the Washington DC Principles for Free Access to Science, a set of guidelines that backs free access to papers but reserves the right of publishers to charge for them for several months after publication.

In London, meanwhile, publishing experts told a parliamentary select committee that scientific societies might have to cut back on their non-publishing activities if open access catches on.

Signatories to the Washington DC principles - most of them US-based societies say they need publishing revenues to pay for everything else they do, from running conferences to educating the public. "Any profit that we make goes back into the development of the next generation of scientists," says Martin Frank, executive director of the American Physiological Society and spokesman for the group.

The societies say they are responding to the launch of the Public Library of Science's first journal, PLoS Biology, last October. The free online journal generates income by charging authors $\$ 1,500$ to publish a paper.
But the societies say that the backers of PLoS failed to acknowledge that both traditional and open-access publishing can coexist. "People were saying that PLoS was plotting the overthrow of the scientific publishing system," says Frank.

Many society editors say it would be impossible to generate income for other activities if they only raised money through payments from authors. An international survey of 4,000 researchers' attitudes to open-access publishing, released on 18 March by information scientists at City University, London, suggested that fewer than $5 \%$ of authors would be willing to pay more than $\$ 1,000$ to publish a paper.

Rhonda Oliver, managing director of Portland Press, the London-based publish-

\section{US Army backs Swedish cell study}

\section{Alison Abbott, Munich}

The US Department of Defense is giving $\$ 240,000$ to Lund University, Sweden, in order to fund research into treating Parkinson's disease with human embryonic stem cells.

The unlikely partnership came about after Patrik Brundin, the Swedish project's principal investigator, was advised to submit a proposal to the US Army's Neurotoxin Exposure Treatment Research Program. The recommendation came from the New Yorkbased Michael J. Fox Foundation, which supports research into Parkinson's.

The army's programme supports research into neurological diseases in case neurotoxins are used as weapons of war. It considers grant applications from researchers anywhere in the world, as do many US government research programmes.

Parkinson's disease occurs when dopamine-producing cells degenerate in a brain area called the substantia nigra.
Brundin was involved in pioneering studies in the late 1980s that tried to replace those cells using substantia nigra tissue from aborted human embryos.

In the small series of clinical trials in Sweden and the United States, some patients did very well, some less well, some did not respond and a small number suffered the side effect called dyskinesia, where a patient has uncontrolled movement of the head or limbs.

"We do not understand the basis of this inherent variability," says Brundin, who points out that the supply of embryonic tissue is unreliable and could be one source of variation. Human embryonic stem cells that are stimulated to differentiate into dopamine-producing cells could provide more reliable material for transplantation.

His team will first develop methods of differentiating a stem cell line produced at the University of Gothenburg, Sweden. The cell line is one of those approved for federal ing arm of the Biochemical Society, says she would need to charge almost twice that just to keep the society's journals afloat. Oliver says the publications also give a surplus of $\mathfrak{E} 500,000$ (US\$920,000) to the society every year, and that the

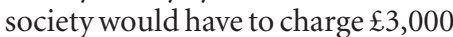
for each paper published to keep that going.

Similar concerns have been raised by witnesses to the inquiry into scientific publishing run by the UK House of Commons' Science and Technology Committee, which began hearings on 1 March and plans to report this summer.

But the editorial director of BioMed Central, a London-based publisher of more than 100 open-access journals disagrees: Peter Newmark argues that societies are basing estimates for author payments on existing publication systems. He says that the figure would be much lower if journals moved to online-only publication and factored in savings generated by not having to print journals or sell subscriptions.

Newmark also questions whether the societies should be channelling publication revenue into other activities. He says that grants and education programmes are valuable, but points out that the money ultimately comes from public sources. "They're taxing the universities to support the societies," he says.

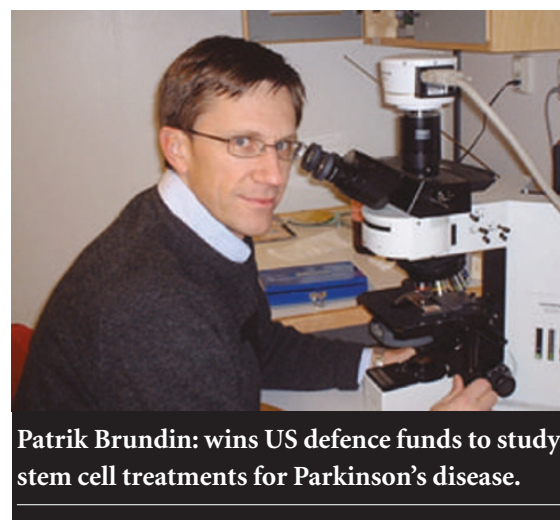

funding by the US National Institutes of Health. These cells will be transplanted into the brains of rats which have a type of parkinsonism induced by chemical damage. The condition of the rats will be continuously monitored, as will the survival and correct biological functioning of the transplanted cells.

"In this way we hope to get some insight, under very controlled research conditions, into the variability of transplanted tissue in parkinsonism," Brundin says. 